\title{
The Impact of E-Banking on the use of Banking Services and Customers Satisfaction
}

\author{
Dr. Prof. Renu1, Kuldeep Singh² \\ ${ }^{1}$ Associate professor, ${ }^{2}$ Stdedent LL.M \\ ${ }^{1,2}$ Chandigarh University, Mohali, Punjab, India
}

\begin{abstract}
How to cite this paper: Dr. Prof. Renu | Kuldeep Singh "The Impact of E-Banking on the use of Banking Services and Customers Satisfaction" Published in International Journal of Trend in Scientific Research and Development (ijtsrd), ISSN: 24566470, Volume-3 | Issue-4, June 2019, pp.20-23, URL: https://www.ijtsrd.c om/papers/ijtsrd23 559.pdf

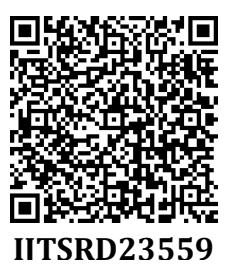

Copyright (C) 2019 by author(s) and International Journal of Trend in Scientific Research and Development Journal. This is an Open Access article distributed under the terms of the Creative Commons

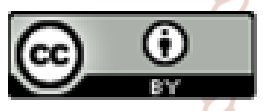
Attribution License (CC BY 4.0) (http://creativecommons.org/licenses/ by/4.0)
\end{abstract}

ABSTRACT

In the modern era of technology. Every work in the human life is much easier than the traditional one. Due to technology everything is computerized. Banking is also the one from all of them. After the 18th centaury banking industry has been much developed in the field of technology. Due to technology there are so many innovations in banking sector. Every work in the banking industry is computerized from opening of account to transfer of money through e-banking, which needs not to go to the banks and stand in a long queues for a long time which helps the customers as well as banking institutions to do work easy, efficient and fast. E-Banking also makes the competition between different banks for providing a better services to their customers and also attract the more and more customers. The different amendments by the RBI they made to follow the mandatory rules and regulations, guidelines, instructions for the banks and customers, It helps to provide privacy to the customers about their account and every transaction while operating their account at the time of online banking. But at this present scenario few of the customers are not take the advantage of this e banking due to unawareness and uneducation(because technology demands knowledge to operate it). In some of the banks public sector banks few of the staff is with old age ones officials they have very less knowledge about computerized banking/ e-banking and this thing takes long time when they do any transaction. And these are the burden on the public sector banks to spent much money on their training that how to operate the computers while work in the bank to deal any transaction. Otherwise technology has played pivotal role in banking sector. Internet banking is increasingly becoming "Need to have than a Nice to have service" From the prespective banking product and service being offerd through internet debit and credit cards, mobile, e banking is nothing more traditional banking service distributed through an economic communication backbone. ${ }^{1}$

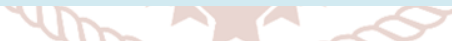

KEYWORDS: E-banking, banking, Customer satisfaction, ATM

\section{INTRODUCTION}

The advent of computer has proved to be a great miracle of the twentieth centuary. The invention of computers has been a great boon to the mankind in every walk of life. Now we have adopted a computer banking which has revolutionized the working of the banking. it has proved a new age of the banking. The process of computerization in Indian Banks started in early 80s when the first committee on computerization i.e Rangajan Committee gave its recommendations in the year 1984. The second report of Rangrajan Committee in the year 1989 gave the much needed pace to expedite the computerization. The major objective of computerization can be improved customer service better housekeeping, quicker decision making and increased profits and productivity ${ }^{1}$.

Online banking also known as Internet banking, e-banking or

${ }^{1}$ R.N.CHOUDARY,Banking Law,378,Central Law Publication. virtual banking, is an electronic payment system that enables customers of a bank or other financial institution to conduct a range of a financial transactions through the financial institutions websites. The online banking system will typically connect to or be part of the core banking system operated by a bank and is in contrast to branch banking which was the traditional way customers accessed banking services ${ }^{2}$.

E-banking is an electronic consumer interface and alternative channel of distribution for banking services and products. E-banking is a process through which banking consumer manage their banking transaction even without visiting a bank branch ${ }^{3}$.

\footnotetext{
${ }^{2}$ www.scribd.com)visitedon2/02/20198;56pm

${ }^{3}$ Chapter 3 Review of Literature Shodganga Inflibnet.ac.in, visited on 01/02/2019at12:00pm
} 


\section{DEFINITION}

E- banking is defined the automated delivery of new and traditional banking products and services directly to customers through electronic, interactive communication channels. E banking includes the systems that enable financial institution customers, individuals or businessman, to access to accounts, transact business or obtain information on financial products and services through a public or private network, including the internet. customer access e banking services using an intelligent electronic device, such as personal computer (PC), personal digital assistance (PDA) automated teller machine (ATM) kiosk or Touch tone telephone. While the risks and controls are similar for the various e banking access channels ${ }^{4}$.

\section{Meaning of E -banking}

E-Bank is the electronic bank that provides the financial service for the individual clients by means of internet.

\section{ADVANTAGES TO THE BANKING INSTITUTIONS.}

1. E- banking helps in reducing the cost of delivering the services to the customers.

2. It provides banks with competitive advantage among their peers.

3. It reduces the use of paper money that helps the central bank in printing less paper notes.

4. Through websites, banks can earn revenue by promotional activities.

5. The customer can easily transfer the funds from one place to another place electronically.

6. The customer can obtain funds at any time from ATMs.

7. Customer can avail e-banking facility at anytime, anyplace, therefore there is a need to invest more and more on relevant infrastructure.

\section{ADVANTAGES TO THE CUSTOMERS}

1. E-banking delivers $24 * 7$ services to customers.

2. Easy access to account information in quick time.

3. Payment can be made online for the purchase of goods and services.

4. The customer can easily transfer the funds from one place to another place electronically.

5. The customer can obtain funds at any time from ATMs.

6. With e-banking customer can check account balance,can get statement of their account, apply loans, and collect other information. ${ }^{5}$

\section{DISADVANTAGES OF E BANKING}

1. Some credit units are limited in their products offering.

2. saving and credit cooperatives, and in particular small local cooperatives, strive to match the level of convenience. That many bank offer their customers although many are part of shares network and that increase channel available to its members.

3. One must qualify for membership.

4. One must pay a membership fee to join. ${ }^{6}$

5. Danger of giving card number when buying online.

6. Abuse of bank cards by fraudsters at ATMs.

\footnotetext{
${ }^{4} \mathrm{https}$ /ithanbookffiec.gov) visited on $02 / 02 / 2019$ at 9;49

pm.

${ }^{5}$ Shodganga.inflibnet.ac.in,visited on $22 / 02 / 2019$ at 10:00 am

${ }^{6}$ https://mangalmay.org.visitedon03/02/2019at4:00pm.
}

It does not include that customer who do not use current $\mathrm{e}$ banking which would to compare the attitude of e banking users and non users toward e banking. It also limited to bank customer only that started e banking service it does not fully covered those who do not start it.

Most available data of previous research conducted may not explain specific to our country context to the area. ${ }^{7}$

\section{IMPACT OF E BANKING}

E banking transactions are much cheaper than branch or phone transaction, This could turn yesterday competitive advantage/ a large branch network into a comparative disadvantage allowing e- bank to undercut bricks and motor banks this is commonly known as "beached dinosaur" theory. E-bank are easy to setup so lots of new in trends will arrived. E-Banking give consumer much more choice.Consumer will the less inclined to remain loyal. EBanking have already found retail banking only becomes profitable once a large critical mass is achieved.

E-Banking transaction needs some interface to communicate with banking customer. All the electronic transaction throw some interface.E-Banking is just banking offered by new delivery channel. It simply gives consumers another service. The start up cost of an e-bank are very high. Establishing a trusted brand is very costly as it require significant advertising expenditure in addition to the purchase of expensive technology. Traditional bank are find to difficult to involve not only they unable to make acquisition for cash as oppose to being able to offer shares, they unable to obtain additional capital from stock market. This is contrast to the situation for internet firms for home it seems relatively easy to interact investments.

E-Banking has become is integral part of the global financial environment in order to meet different requirement of customer in banking sector, thereby meeting the increase expectation in Indian banking system. E-Banking has been popular among computer literates for many years, its popularity is growing exponentially as internet users grow and people discover the different benefits that are provided by online banking. 8

\section{TYPES OF E-BANKING}

1. 1 Using a computer to perform direct banking make a balance enquiry, inter account transfer and pay linked.

2. 2 Deposit, With drawls, inter account transfer and payment of linked account at an ATM.

3. 3 Using a telephone to perform a direct banking/make a balance enquiry inter account transfer and pay linked accounts.

4. 4 Buying and paying for goods and service using debit cards and smart card without having to carry cash or cheque book.

\section{LEGAL PROVISIONS REGARDING E BANKING}

Law cannot possibly be expected to keep pace with changes in technology. The recent debacle of virtual voyeurism has brought out, amongst other Thing the inadequacy and vulnerability of the laws governing use of internet. Fixing liability, recording and reproducing evidence, ascertaining jurisdiction are problems which show little sign of easing.

\footnotetext{
${ }^{7}$ omicsonline.org, vsited on 27/03/2019, at 10:00 PM

8 journal sagepub.com
} 
Concerns over security and misuse pertaining to e-banking activity have been mounting as more banks in India foray into electronic banking. ${ }^{9}$

Though there was a message to banks that they should be formed for public good, since inception, banking has always been a commercial venture, the prime motive of banks being to enlarge profits. And lately adoption of new economic environment such as liberalisation, privatization and globalization has caused concern in banking sector. Indian banks have also undergone as weeping change where deregulation, technological innovations and globalization are significantly affecting the banking services. ${ }^{10}$

The emergence of internet banking has made many banks to rethink their Information Technology (IT) strategies in competitive markets. It is suggested that the banks that fail to respond to the emergence of internet banking in the market are likely to lose customer and that the cost of offering internet banking services is less than the cost of keeping branch banking. ${ }^{11}$

India has great prospect compared to other developing nations to leverage the potential of E-Banking and build a cash light economy. In addition to IT edge and relatively dense population, the Government of India (GOI) has clearly determined to achieve financial inclusion ${ }^{12}$ and is taking aggressive steps to see this happens. ${ }^{13}$

Rendering financial services to the un-served or poor through a market led approach is important for sustainability of financial inclusion. There are many reforms and enrolment drives which have been undertaken by the Reserve Bank of India (herein referred as RBI) and GOI in matter of financial inclusion over the last decade. The RBI and GOI policy initiatives and reforms have considerably helped the development of E-Banking system.

The reforms include adoption of technology prototypes like smart cards, mobile based options, debit cards and credit cards. These facilities and advancement have given vent to more market driven environment, which is in fact, the future face of the Indian economy. Adoption of new technology has resulted in risks ${ }^{14}$. The legal risk is one which arises from violation of, or non-conformance with laws, rules,

${ }^{9}$ Ankur Gupta, "Data Protection in consumer E-Banking", Journal of Internet Banking and Commerce, 1 vol. 1, April (2006).

${ }^{10}$ Rimpi Kaur, "An Impact of IT on Branch Productivity of Indian Banking in the Era of Transformation", Journal of Internet Banking and Commerce,2, vol. 17, December, (2012).

${ }^{11}$ Salim Al-Hajri \& Arthur Tatnall, "Technological Innovation and the Adoption of Internet Banking in Oman"The Electronic Journal for Virtual Organisations and Networks,60, vol. 10, August, (2008).

${ }^{12}$ Financial inclusion or inclusive financing is the delivery of financial services at affordable costs to sections of disadvantaged and low-income segments of society.

${ }^{13}$ Graham.A.N.Wright, et. al., "Why E/M-Banking Will Soon Reach Scale In India", inhttp://www.microsave.net, Accessed on 23/03/2019at6:00pm.

${ }^{14}$ Law and Regulation of Electronic Finance and Internet Banking, 2007, in U.K., Electronic Fund Transfer Act, 1978, in U.S.A are few examples such regulations. regulations, prescribed practices, or when the legal rights and obligation of the in certain cases are uncertain and applicability of laws and rules is also ambiguous.

To regulate the banking in India: There are many statutes, which forms the legal framework such as : Banking Regulation Act, 1949. 15

The Reserve Bank of India Act.193416

The Negotiable Instruments Act, 1881.17

The Indian Contract Act, 1882. ${ }^{18}$

Foreign Exchange Management Act, 1999.19

Consumer Protection Act, $1986 .^{20}$

Prevention of Money Laundering Act, 2002. ${ }^{21}$

Bankers Books Evidence Act, 1891. ${ }^{22}$

Indian Evidence Act, $1872 .{ }^{23}$

Indian Penal Code, 1860.24

The Payment and Settlement Systems Act, 2007.25 and most importantly Information Technology Act, 2000. ${ }^{26}$

\section{Conclusion}

E-banking enable better business anywhere, anytime. It represent a tremendous opportunity. E-banking is also advantageous not only for customer even advantageous for banks as well. customers do not have to go branches in order to access their accounts, make withdrawals and deposits. E banking is more accessible, convenient, secure, more fast and cost effective for the customers as well as banks. which is the competition in the market. for busy executive, students and home markers, E- Banking is virtual blessings. Central government/RBI has made many different provisions to eliminate the problem in banking sectors like to recruit the young and capable recruiters who have specialized knowlwdge in the field of technology. Customers demands Innovations which helps the work much easier time saving and efficient, this thing encourage the competition between the banks to provide better service new and efficient technology to the customers.

\section{REFERENCE}

[1] R. N.CHOUDARY, Banking Law,378, central law publication.

[2] (www.scribd.com)visitedon26/0/2019at8;56pm

[3] chapter 3 review of literature p47, shodganga inflibnet.ac.in, visited on 02/02/2019

[4] https/ithanbookffiec.gov visite d on $02 / 01 / 2019$ at 9;49 pm.

[5] Sodganga.inflibnet.ac.in
15 Act No. 10 of 1949
${ }^{16}$ Act No. 2 of 1934.
17 Act No. 26 of 1881.
${ }^{18}$ Act No. 9 of 1872.
${ }^{19}$ Act No. 42 of 1999.
${ }^{20}$ Act No. 68 of 1986 .
${ }^{21}$ Act No. 15 of 2003.
22 Act No. 18 of 1891
23 Act No. 1 of 1872 .
${ }^{24}$ Act No. 45 of 1860.
${ }^{25}$ Act 51 of 2007.
${ }^{26}$ Act No. 21 of 2000 
International Journal of Trend in Scientific Research and Development (IJTSRD) @ www.ijtsrd.com eISSN: 2456-6470

[6] https://mangalmay.org.visitedon15/01/2019at2:00pm

[7] Ankur Gupta, 'Data Protection in consumer E-Banking', Journal of Internet Banking and Commerce,,vol. 11, April (2006), p.1.

[8] Rimpi Kaur, 'An Impact of IT on Branch Productivity of Indian Banking in the Era ofTransformation', Journal of Internet Banking and Commerce, vol. 17, December, (2012), p.2.

[9] Salim Al-Hajri \& Arthur Tatnall, "Technological Innovation and the Adoption of Internet Banking in Oman', The Electronic Journal for Virtual Organisations and Networks, vol. 10, August, (2008), p.60

[10] Financial inclusion or inclusive financing is the delivery of financial services at affordable costs to sections of disadvantaged and low-income segments of society.

[11] Graham A. N. Wright, et. al., 'Why E/M-Banking Will Soon Reach Scale In India', inhttp://www.microsave.net, Accessed on 24th January, 2013.

[12] Legal risk, security risk, market risk.
[13] Law and Regulation of Electronic Finance and Internet Banking, 2007, in U.K., Electronic Fund Transfer Act, 1978, in U.S.A are few examples such regulations.

[14] Act No. 10 of 1949.

[15] Act No. 2 of 1934.

[16] Act No. 26 of 1881.

[17] Act No. 9 of 1872.

[18] Act No. 42 of 1999.

[19] Act No. 68 of 1986.

[20] Act No. 15 of 2003.

[21] Act No. 18 of 1891

[22] Act No. 1 of 1872.

[23] Act No. 45 of 1860.

[24] Act 51 of 2007.

[25] Act No. 21 of 2000.

[26] Mishra.A. K (2005) "internet banking in india, part1", www.bank net india.com.

[27] Gupta.V,(2002) "overview of e-banking" : A global prospective bankers 